\title{
Karakteristik Fungsional, Fisik dan Sensori Sereal Sarapan Jagung yang Disubstitusi Bekatul Fermentasi
}

\author{
Functional, Physical and Sensory Characteristics of Corn Breakfast Cereals Substituted by Fermented \\ Rice Bran \\ Feri Kusnandar*, Suryani, Slamet Budijanto \\ Departemen Ilmu dan Teknologi Pangan, Fakultas Teknologi Pertanian, IPB University, Bogor \\ *Korespondensi dengan penulis (fkusnandar@apps.ipb.ac.id) \\ Artikel ini dikirim pada tanggal 5 April 2020 dan dinyatakan diterima tanggal 19 Juli 2020. Artikel ini juga dipublikasi secara online melalui \\ https://ejournal2.undip.ac.id/index.php/jatp. Hak cipta dilindungi undang-undang. Dilarang diperbanyak untuk tujuan komersial. \\ Diproduksi oleh Indonesian Food Technologists® (C2020
}

\begin{abstract}
Abstrak
Bekatul dari hasil samping penggilingan padi memiliki komponen gizi dan non-gizi. Proses fermentasi pada bekatul diketahui dapat meningkatkan komponen fenolik dan aktivitas antioksidannya. Penelitian ini menggunakan bekatul yang difermentasi dengan kapang Rhizopus oligosporus selama 72 jam dan diformulasikan sebanyak 15, 20 , dan $25 \%$ ke dalam sereal sarapan jagung. Bekatul tanpa fermentasi juga dibuat sebagai pembanding. Karakteristik fungsional yang berupa aktivitas antioksidan, kadar total fenol, serat pangan, mutu fisik yang berupa derajat pengembangan (DP), indeks penyerapan air (IPA), kelarutan air (IKA), kekerasan dan kerenyahan, serta mutu sensori sereal sarapan dianalisis dengan menggunakan rancangan acak lengkap dua faktor dan diuji lanjut dengan Duncan Multiple Range Test. Hasil penelitian menunjukkan bahwa penambahan bekatul fermentasi mampu meningkatkan aktivitas antioksidan dan kadar total fenol, namun memberikan penerimaan sensori yang lebih rendah dibandingkan formula sereal sarapan yang lain. Kesimpulannya, substitusi dengan $25 \%$ bekatul tanpa fermentasi dalah yang paling disukai berdasarkan analisis warna, aroma, rasa, dan tekstur. Sereal sarapan dengan formulasi tersebut memberikan nilai DP, IPA, dan IKA yang spesifik dan memberikan tingkat kekerasan dan kerenyahan yang dapat diterima panelis, serta menunjukkan aktivitas antioksidan, kandungan total fenol dan serat pangan yang tergolong tinggi.
\end{abstract}

Kata kunci: bekatul fermentasi; sereal sarapan, fungsional, mutu fisik, mutu sensori

\begin{abstract}
Rice bran as a by-product of rice mills contains a relatively high nutritious components, such as phenolic compounds. Fermentation process in rice bran may increase phenolic compounds and antioxidant activity. In this study, fermented rice bran using Rhizopus oligosporus for 72 hours were formulated into corn-based breakfast cereals at the concentration of 15, 20, and $20 \%$. Non fermented rice brand was also used as a comparison. The functional characteristics that consisted of antioxidant activity, total phenol, and dietary fiber; physical quality, i.e. degree of expansion (DE), water absorption index (WAI), solubility index (SI), hardness and crispness; and sensory quality were analysed using a two-factor randomized experimental design followed by Duncan Multiple Range Test. As a result, fermented rice bran yielded less acceptable breakfast cereals than that of a non-fermented cereal, although the antioxidant activity and total phenol increased along the fermented rice brand. As a conclusion, substitusion with $25 \%$ non-fermented rice bran was the most accepatable in terms of color, aroma, taste and texture compared to other formulations. The formulated breakfast cereal had specified DE, WAI and SI, hardness and crispness, as well as showed high values of antioxidant activity, total phenol, and dietary fiber.
\end{abstract}

Keywords: rice bran, fermentation, breakfast cereal, functional, physical quality; sensory quality

\section{Pendahuluan}

Bekatul merupakan hasil samping dari penggilingan padi, yaitu serbuk halus coklat dari lapisan terluar dari beras pecah kulit (Sharif et al., 2014). Hasil penggilingan padi dan penyosohan beras menghasilkan beras $(70 \%)$, bekatul ( $8 \%$ ) dan lembaga (2\%) (Gul et al., 2015). BPS (2018) melaporkan bahwa produksi padi Indonesia pada tahun 2018 mencapai 56,54 juta ton yang menyisakan bekatul sebesar 4,52 juta ton. Jumlah bekatul yang besar ini berpotensi untuk dimanfaatkan sebagai ingridien pangan.

Bekatul disusun dari lapisan perikarp, testa dan aleuron yang mengandung komponen gizi makro yang bervariasi tinggi yang dipengaruhi oleh varietas berasnya, yaitu protein $(11,8-13,0 \%)$, lemak $(10,1$ -
$12,4 \%)$, karbohidrat $(51,1-55,0 \%)$, dan abu $(5,2-7,3 \%)$ (Luh 1991). Bekatul juga mengandung serat pangan (11,77-12,68\%), komponen fenolik $(1,96-6,65 \%), \gamma$ oryzanol $(1,52-9,12 \mathrm{mg} / \mathrm{g})$, a-tokoferol $(41,36-43,57$ $\mu \mathrm{g} / \mathrm{g}$ ), $\gamma$-tokoferol $(25.00-37,97-\mu \mathrm{g} / \mathrm{g}$ ) (Moongngarm et al., 2012). Selain itu, bekatul juga mengandung vitamin, seperti asam pantotenat $(7 \mathrm{mg} / 100 \mathrm{~g})$, tiamin $(3,0$ $\mathrm{mg} / 100 \mathrm{~g})$, riboflavin $(0,4 \mathrm{mg} / 100 \mathrm{~g})$, niasin $(43 \mathrm{mg} / 100$ g) dan piridoksin $(0,49 \mathrm{mg} / 100 \mathrm{~g})$ (Rao, 2000). Komponen lain yang terdapat dalam bekatul adalah asam fenolik (0,89-1,22 $\mathrm{mg}$ GAE/mg ekstrak), flavonoid (0,66-1,93 mg GAE/100 g), antosianin (109,5-256,6 $\mathrm{mg} / 100 \mathrm{~g}$ ) (Muntana dan Prasong, 2010; Sompong et al., 2011; Pengkumsri et al., 2015; Henderson et al., 2012). Di antara senyawa bioaktif yang terdapat dalam bekatul 
tersebut berpotensi memiliki manfaat fungsional bagi kesehatan (Bazzano, 2008; Xu et al., 2001; Ghatak and Panchal, 2012).

Walaupun bekatul mengandung zat gizi dan komponen bioaktif yang baik, namun pemanfaatannya sebagai ingridien pangan masih terbatas. Hal ini disebabkan oleh rasa dan tekstur bekatul yang kurang disukai, disamping juga mudah mengalami ketengikan (Tuarita et al., 2017; Faizah et al., 2020). Namun demikian, proses fermentasi dari bekatul oleh kapang dinilai dapat meningkatkan kandungan gizi dan memperbaiki sifat sensori dari bekatul (Ryan et al., 2011; Rashid et al., 2015). Schmidt and Furlong (2012) dan Novelli et al. (2016) melaporkan bahwa fermentasi kapang dapat meningkatkan ketersediaan (availabilitas) senyawa bioaktif pada bekatul melalui aktivitas kapang dalam memecah lignoselulosa dan polisakarida. Kapang ini juga dapat meningkatkan kapasitas antioksidan dan jenis senyawa fenolik (Sousa dan Courreia, 2012; Sivamaruthi et al., 2018). Razak et al. (2015) melaporkan bahwa komponen total fenol mengalami peningkatan setelah difermentasi dengan Rhizopus oligosporus, yaitu dari 3,93 menjadi 7,54 mg EAG/g.

Dalam penelitian lain, Schimidt et al. (2014) dan Rashid et al. (2015) melaporkan bahwa bekatul yang difermentasi dengan kapang Rhizopus oryzae mengalami peningkatan senyawa fenolik $(2,4-5,1 \mathrm{mg} / \mathrm{g})$. Faizah et al. (2020) melaporkan bahwa bekatul yang difermentasi kapang selama 72 jam menunjukkan peningkatan aktivitas antioksidan tertinggi, dengan kadar total senyawa fenolik dan kadar $\gamma$-oryzanol yang meningkat masing-masing menjadi 3,6-3,9 mg EAG/g dan 10,74-12,93 $\mathrm{mg} / \mathrm{g}$. Dalam penelitian lain, Silveira dan Furlong (2009) menyatakan bahwa fermentasi kapang selama 72 jam dapat meningkatkan kandungan protein, dan memperbaiki daya ikat air dan protein terlarut dari bekatul. $\mathrm{Di}$ samping meningkatkan komponen bioaktif, proses fermentasi kapang Rhizopus oligosporus juga dapat memperbaiki tekstur akibat aktivitas pemecahan polisakarida (termasuk selulosa) oleh kapang menjadi serat pangan larut air, di samping juga memperbaiki flavornya (Vong et al., 2018). Hasil penelitian ini menunjukkan bahwa bekatul yang difermentasi kapang memiliki kadungan gizi dan komponen bioaktif yang lebih baik, sehingga berpotensi untuk dimanfaatkan sebagai ingridien fungsional, salah satunya adalah sebagai bahan pensubstitusi dalam produk sereal sarapan.

Sereal sarapan jagung merupakan salah satu alternatif makanan sarapan yang terus berkembang seiring dengan mobilitas masyarakat yang semakin tinggi yang memerlukan makanan yang praktis. Sereal sarapan berkontribusi pada pemenuhan zat gizi makro dan mikro (Thomas et al,, 2013). Sereal sarapan umumnya diproses secara komersial dengan menggunakan teknologi ekstrusi panas dan produk yang dihasilkan mengembang (puffing), memiliki kemampuan menyerap dan larut dalam air, tidak keras dan renyah (Oliveira et al., 2018). Salah satu sereal sarapan yang banyak dikonsumsi adalah sarapan dari jagung. Sereal sarapan jagung mengacu pada SNI 01-2886-2000 (BSN,
2000) yang mengatur komposisi kandungan gizinya. Berdasarkan pada perkembangan yang pesat ini, maka perlu adanya penelitian inovatif yang memanfaatkan bekatul fermentasi sebagai komponen penyusun sereal sarapan. Penelitian semacam ini belum banyak dilakukan, sehingga penelitian ini bertujuan untuk memanfaatkan bekatul sebagai penyusun sereal sarapan jagung, yang diharapkan dapat meningkatkan kandungan komponen bioaktif dalam sereal sarapan, dengan meminimalkan penurunan zat gizi dan mutu sensorinya. Penelitian diharapkan dapat membawa manfaat pada pengembangan sereal sarapan jagung dan penggunaan bahan lokal yang mudah dijumpai di Indonesia.

\section{Materi dan Metode \\ Materi}

Bahan yang digunakan adalah bekatul padi varietas Indica dalam bentuk gabah kering giling yang diperoleh dari petani di Jasinga Bogor dan tepung jagung yang diperoleh dari supplier lokal. Starter kapang yang digunakan untuk fermentasi adalah Rhizopus oligosporus yang diperoleh dari yang diperoleh dari IPB Culture Collection, Institut Pertanian Bogor. Media Potato Dextrose Agar atau PDA dan akuades digunakan untuk penumbuhan kultur untuk fermentasi. Bahan utama yang digunakan untuk analisis kimiawi, meliputi $\mathrm{NaOH}$, asam borat, indikator bromcressol green, metil merah, $\mathrm{HCl}$, heksan, termamyl, $\mathrm{NaOH}$, protease, $\mathrm{HCl}$, AMG (amyloglucosidase), etanol, aseton, DPPH, metanol, asam askorbat, asam galat, Folin-Ciocalteau, dan $\mathrm{Na}_{2} \mathrm{CO}_{3}$. Seluruh bahan kimia yang digunakan dalam analisis kimia adalah analytical grade.

Peralatan yang digunakan dalam penelitian ini adalah mesin huller (Satake, Japan), ekstruder ulir ganda (model puffing 2256 Berto Company, UK), autoklaf (HL-343P Gemmy Industrial Corp, Taiwan), UVVis spektrofotometer (Evolution 220 Thermo Scientific ${ }^{\mathrm{TM}}$, USA), sentrifus (Legend XTR, Thermo Scientific, USA), timbangan analitik (ABS 220-4, Germany), soxhlet (Indolab Sam, Indonesia), oven, tanur, penyaring vakum, penangas bergoyang, ayakan 60 mesh, destilator, labu Kjeldahl dan peralatan gelas untuk analisis.

\section{Persiapan bekatul}

Prosedur persiapan bekatul diadopsi dari penelitian sebelumnya (Schmidt et al., 2014 dan Razak et al., 2015) Gabah kering giling dikupas kulitnya dengan mesin huller untuk memperoleh beras pecah kulit. Beras pecah kulit disosoh dengan rice mill (Satake, Japan) selama dua menit, sehinggga diperoleh beras sosoh dan campuran bekatul dan dedak. Bekatul dipisahkan dari dedak dengan ayakan 20 mesh. Bekatul fermentasi disiapkan dengan cara menambahkan air ke dalam bekatul sebanyak $20 \%$ dari berat bekatul, kemudian campuran disterilisasi pada suhu $121{ }^{\circ} \mathrm{C}$ selama 15 menit untuk menginaktivasi enzim lipase yang terdapat dalam bekatul agar tidak mengkatalisis lemak sehingga bekatul tidak mudah tengik (Brunschwiler et al., 2013). Bekatul selanjutnya diinokulasi dengan Rhizopus oligosporus sebanyak $4 \times 10^{6} \mathrm{spora} / \mathrm{g}$ bekatul dan 
difermentasi selama 72 jam pada suhu $30^{\circ} \mathrm{C}$. Selama proses fermentasi, miselium tumbuh secara merata pada permukaan bekatul sehingga bekatul tampak berwarna putih kecoklatan dan memberikan aroma yang harum. Bekatul kemudian dikeringkan dalam oven pada suhu $50^{\circ} \mathrm{C}$ selama 4 jam, dan disimpan pada suhu $18{ }^{\circ} \mathrm{C}$ sebelum digunakan. Bekatul tanpa fermentasi disiapkan dengan cara yang sama, namun tanpa inokukasi kapang. Kedua sampel bekatul dianalisis komposisi kimiawi yang meliputi kadar air, abu, protein, lemak, karbohidrat dan serat pangan; serta aktivitas antioksidan dan kadar total fenol.

\section{Pembuatan Sereal Sarapan}

Sampel bekatul (dengan atau tanpa fermentasi) dicampur dengan tepung jagung tingkat substitusi yang berbeda, yaitu 15,20 , dan $25 \%$ berdasarkan pada prosedur penelian sebelumnya (Budijanto et al., 2012). Campuran tersebut kemudian ditambahkan air $8 \%(\mathrm{v} / \mathrm{b})$ dari berat campuran tepung jagung dan bekatul. Adonan basah kemudian dimasukkan ke dalam ekstruder ulir ganda dengan suhu barrel $127^{\circ} \mathrm{C}$ dan kecepatan ulir pemasukan bawah (auger) $172 \mathrm{rpm}$. Selama proses ekstrusi ini terjadi proses pencampuran, shearing, pencetakan melalui die sehingga terjadi puffing. Sampel sereal sarapan dianalisis aktivitas antioksidan, total senyawa fenolik, total serat pangan, dan sifat fisiknya (derajat pengembangan, indeks penyerapan air, indeks kelarutan air, kekerasan dan kerenyahan) dan penerimaan sensori. Produk dari formula terpilih kemudian dianalisis komposisi kimianya.

\section{Analisis Proksimat dan Serat Pangan}

Analisis kadar air dan kadar abu dilakukan dengan menggunakan metode gravimetri, sedangkan kadar protein dilakukan dengan metode Kjeldahl, serta pengukuran kadar lemak dilakukan dengan menggunakan metode Soxhlet yang semua metode ini, mengacu pada AOAC (2005). Kadar karbohidrat dihitung sebagai by difference. Analisis serat pangan mengacu pada metode AOAC 991.43 (2005).

\section{Analisis Aktivitas Antioksidan}

Metode DPPH (1,1 diphenil pikrihidrazil) dipilih untuk mengukur aktivitas antioksidan dari bekatul dan sereal sarapan. Prosedur pengukuran aktivitas antioksidan dilakukan berdasarkan pada penelitian sebelumnya (Purwanto et al. 2014). Mula-mula sampel diencerkan 200 kali dengan metanol, lalu disentrifugasi untuk dipisahkan bagian supernatannya. Sebanyak $4 \mathrm{ml}$ bagian supernatan kemudian direaksikan dengan $1 \mathrm{ml}$ larutan DPPH 0,5 mM dan diinkubasi dalam ruangan gelap selama 30 menit sehingga terbentuk warna ungu ke kuning. Larutan standar asam askorbat $(0,2,4,6$, dan $8 \mathrm{mg} / \mathrm{l}$ ) juga disiapkan. Absorbansi (A) dari sampel dan larutan standar dibaca pada panjang gelombang $517 \mathrm{~nm}$. Aktivitas antioksidan dinyatakan dalam $\mathrm{mg}$ ascorbic acid equivalent antioxidant capacity (AEAC)/100 g basis kering. Persen penghambatan radikal DPPH atau radical scavenging activity (RSA) dinyatakan dalam persen yang dihitung dari pengurangan angka 1 dari pembagian A sampel dan A kontrol dikalikan seratus.

\section{Analisis Total Fenol}

Prosedur analisis total fenol dilakukan berdasarkan pada penelitian sebelumnya (Andarwulan dan Shetty, 1999). Sebanyak $100 \mathrm{mg}$ sampel ditambah dengan $5 \mathrm{ml} \mathrm{95 \%} \mathrm{etanol.} \mathrm{Campuran} \mathrm{lalu} \mathrm{divorteks} \mathrm{dan}$ disentrifugasi (3000 rpm, 10 menit). Bagian supernatan dipisahkan dan dipipet sebanyak $0,5 \mathrm{ml}$, lalu ditambahkan 0,5 ml etanol $95 \%, 2,5 \mathrm{ml}$ akuades dan 2,5 $\mathrm{ml}$ Folin-Ciocalteau 50\%. Campuran didiamkan selama 5 menit, lalu ditambahkan $0,5 \mathrm{ml}$ larutan $\mathrm{Na}_{2} \mathrm{CO}_{3}$ dengan konsentrasi $5 \%$. Setelah dihomogenisasi dan diinkubasi selama 60 menit, larutan sampel diukur absorbansinya pada panjang gelombang $725 \mathrm{~nm}$. Larutan standar asam galat $(0,50,100,150,200$ dan $250 \mathrm{mg} / \mathrm{l})$ disiapkan untuk pembuatan kurva standar. Total fenol dinyatakan dalam $\mathrm{mg}$ ekuivalen asam galat (EAG)/100 $\mathrm{g}$ basis kering.

\section{Analisis Derajat Pengembangan}

Sampel diambil secara acak, kemudian diukur diameternya dengan menggunakan jangka sorong. Pengukuran dilakukan 5 kali ulangan dan nilainya diratarata. Derajat pengembangan dinyatakan dalam persen antara diameter sampel $(\mathrm{mm})$ terhadap diameter die ekstruder (mm) (Lingko et al., 1981).

\section{Indeks Penyerapan dan Kelarutan Air}

Prosedur analisis penyerapan dan kelarutan air dilakukan dengan memodifikasi penelitian sebelumnya (Dlamini and Solomon, 2016). Sampel dihaluskan dan diayak dengan ayakan 60 mesh, kemudian ditimbang sebanyak $1,25 \mathrm{~g}$ yang kemudian dimasukkan ke dalam tabung sentrifugasi. Sebanyak $20 \mathrm{ml}$ akuades lalu ditambahkan, divortex, dan diinkubasi dalam penangas air (25 ${ }^{\circ} \mathrm{C}$ selama 30 menit), kemudian dilanjutkan dengan sentrifugasi (2000 rpm selama 15 menit). Bagian supernatan dari hasil sentrifugasi ini kemudian dipindahkan ke wadah lain. Tabung sentrifugasi bersama residunya kemudian dipanaskan dalam posisi miring 25 derajat di dalam oven bersuhu $105^{\circ} \mathrm{C}$ sampai semua air menguap $( \pm 3$ jam). Tabung beserta residu tersebut kemudian ditimbang dan dikurangi dengan berat tabung. Indeks penyerapan air (IPA) ditentukan berdasarkan rasio antara bobot air yang hilang dari residu setelah dioven dan bobot awal sampel $(\mathrm{ml} / \mathrm{g})$. Bagian supernatan diambil sebanyak $2 \mathrm{ml}$, lalu ditimbang. Sampel kemudian dikeringkan dalam oven $\left(105{ }^{\circ} \mathrm{C}\right)$ sampai semua air menguap dan ditimbang bobotnya. Indeks kelarutan air (IKA) ditentukan berdasarkan rasio antara residu supernatan setelah dioven dan jumlah supernatan sebelum dioven $(\mathrm{g} / \mathrm{ml})$.

\section{Analisis Tekstur}

Kekerasan dan kerenyahan sampel diukur dengan texture analyzer (TAXT2i, UK) dengan mengacu pada prosedur di manual alat. Probe yang digunakan adalah probe berbentuk jarum. Setting instrumen saat pengukuran adalah pre test speed $(1,5 \mathrm{~mm} /$ detik $)$, test speed $(2,0 \mathrm{~mm} /$ detik), post test speed $(10 \mathrm{~mm} /$ detik $)$, 
rupture test distance $(1,5 \mathrm{~mm} /$ detik), distance $(10 \mathrm{~mm}$ force $100 \mathrm{~g}$ ), dan time (5 detik). Kekerasan ditentukan dari nilai puncak tertinggi dari grafik, sedangkan kerenyahan dihitung dari penjumlahan seluruh nilai puncak dan dibagi dengan banyaknya jumlah puncak (dinyatakan dalam kgf).

\section{Analisis Sensori}

Uji sensori yang digunakan yaitu daya terima sampel (uji rating hedonik) terhadap aroma, warna, rasa, kekerasan, dan penerimaan keseluruhan yang dilakukan sesuai dengan standar prosedur pengukuran uji sensori (BSN, 2006). Penilaian dilakukan oleh 70 orang panelis tidak terlatih. Skala penilaian yang digunakan untuk semua atribut sensori berkisar dari 1 (sangat tidak disukai) hingga 7 (sangat disukai).

\section{Rancangan Penelitian}

Rancangan percobaan yang digunakan adalah rancangan acak lengkap (RAL) dengan dua faktor, yaitu jenis bekatul (tanpa dan dengan fermentasi) sebagai faktor pertama, dan persen substitusi bekatul $(15,20$, dan $25 \%$ ) sebagai faktor kedua. Rentang persentase susbtitusi bekatul yang dipilih merujuk pada Budijanto et al. (2012). Analisis ragam dan uji lanjut Duncan pada taraf signifikansi $5 \%$ dilakukan dengan menggunakan program SPSS 20.0.

\section{Hasil dan Pembahasan \\ Karakteristik Bekatul}

Komposisi kimia bekatul mengalami perubahan setelah proses fermentasi. Kadar lemak dan karbohidrat dinilai menurun, sedangkan kadar abu, protein, dan serat pangan dinilai meningkat (Tabel 1). Perubahan komposisi ini disebabkan oleh adanya pertumbuhan kapang yang membutuhkan nutrisi untuk pertumbuhan dengan memanfaatkan zat gizi pada bekatul (Olanipekun et al., 2009; Cempaka et al., 2018). Perubahan komposisi kimia juga dapat disebabkan oleh pembentukan miselium kapang Rhizopus oligosporus yang memiliki protein dan serat yang tinggi (Olanipekun et al., 2009; Oliveira et al., 2010; Razak et al., 2015). Bila dibandingkan dengan komposisi kimia tepung jagung yang digunakan dalam penelitian ini, maka bekatul tanpa dan dengan fermentasi memiliki kadar protein, kadar lemak dan serat pangan yang lebih tinggi, namun mengandung kadar air, abu dan karbohidrat yang lebih rendah (Tabel 1).

Sifat fungsional bekatul dievaluasi dari aktivitas antioksidan dan kadar total fenol. Bekatul tanpa fermentasi memiliki aktivitas antioksidan sebesar $66,28 \%$ yang setara dengan kemampuan mereduksi radikal bebas dari vitamin C $(145,16$ AEAC $\mathrm{mg} / 100 \mathrm{~g})$. Aktivitas antioksidan meningkat secara nyata $(p<0,05)$ setelah difermentasi, yaitu menjadi $87,29 \%$ atau setara dengan 191,80 AEAC mg/100 g (Tabel 2). Schmidt et al. (2014) juga melaporkan bahwa aktivitas antioksidan bekatul yang difermentasi selama 120 jam mengalami peningkatan menjadi $213-250 \mathrm{mg} / \mathrm{g}$. Peningkatan aktivitas antioksidan dapat diikuti oleh peningkatan komponen asam fenolat akibat pemecahan selulosa dan hemiseluloa pada dinding sel yang mengakibatkan terbebasnya komponen fenolik, seperti asam ferulat, asam galat, antosianin dan oryzanol (Schmidt and Furlong, 2012; Schmidt et al., 2014; Jun et al., 2015). Razak et al. (2015) juga melaporkan bahwa senyawa fenolik bekatul yang difermentasi meningkat dari 3,93 menjadi 7,54 mg EAG/g (dengan Rizhopus oligosporus), 7,69 mg EAG/g (dengan Monascus purpureus) dan 8,13 mg EAG/g (dengan campuran Rizhopus oligosporus dan Monascus purpureus).

Total fenol bekatul yang difermentasi selama 72 jam mengalami peningkatan yang nyata $(24,4 \%)$ dibandingkan tanpa fermentasi, yaitu dari 1125,01 menjadi 1400,06 mg EAG/100 g (Tabel 2) Peningkatan kandungan total fenol ini tidak setinggi yang dilaporkan oleh Schmidt et al. (2014), yaitu sebesar $110 \%$. Perbedaan ini dapat disebabkan oleh perbedaan varietas padi dan waktu fermentasi. Peningkatan total fenol dapat disebabkan oleh kemampuan kapang dalam menghasilkan enzim pemecah lignin dan memiliki sistem oksidatif ligniolitik yang mendegradasi cincin fenil sehingga meningkatkan komponen fenol bebas (Martins et al., 2011). Menurut Razak et al. (2015), komponen fenolik seperti asam ferulat (komponen fenolik utama pada bekatul) dapat bertindak sebagai radical scavengers terhadap DPPH dan NO (nitrogen oksida), sehingga meningkatkan aktivitas antioksidannya. Hal ini bersesuaian dengan nilai aktivitas antioksidan dari bekatul yang lebih tinggi pada kadar total fenol yang lebih tinggi.

\section{Karakteristik Fisikokimia Sereal Sarapan}

Sereal sarapan yang disubstitusi dengan bekatul tanpa fermentasi menunjukkan aktivitas antioksidan yang meningkat dengan semakin tingginya jumlah bekatul yang ditambahkan (Tabel 3 ). Sereal sarapan yang diformulasi dengan bekatul fermentasi pada tingkat substitusi yang sama dengan bekatul tanpa fermentasi memiliki aktivitas antioksidan yang lebih tinggi, baik dinyatakan sebagai AEAC maupun \%RSA, walaupun lebih rendah dibandingkan dari bekatulnya. Hasil analisis ragam menunjukkan peningkatan yang nyata $(p<0,05)$ dari aktivitas antioksidan sereal sarapan yang ditambahkan bekatul fermentasi dibandingkan bekatul tanpa fermentasi.

Kandungan total fenol sereal sarapan menurun dibandingkan dengan kandungan total fenol pada bekatul (Tabel 3). Penurunan tersebut mencapai $41-59 \%$ dari total fenol bahan. Di samping karena sereal sarapan tidak dibuat $100 \%$ dari bekatul, penyebab lainnya yang mungkin terjadi adalah adanya senyawa fenol yang rusak oleh pemanasan selama proses ekstrusi. Menurut Chipurura et al. (2010), proses pemanasan dapat menurunkan kandungan senyawa fenolik pada bahan pangan.

Peningkatan aktivitas antioksidan juga linear dengan peningkatan kadar total fenol dari sereal sarapan yang disubstitusi dengan bekatul, baik tanpa maupun dengan fermentasi (Tabel 3). Substitusi tepung jagung dengan bekatul tanpa fermentasi dan bekatul fermentasi berpengaruh terhadap kadar total fenol 
sereal sarapan. Substitusi bekatul fermentasi sebesar $25 \%$ menunjukkan kandungan total fenol tertinggi $(163,37 \mathrm{EAG} / 100 \mathrm{~g})$, sedangkan sereal sarapan dengan substitusi $15 \%$ bekatul tanpa fermentasi menunjukkan kadar total fenol terendah $(67,66 \mathrm{mg}$ EAG/100 g). Hal ini dapat terjadi karena kandungan total fenol dari bekatul yang difermentasi yang lebih tinggi dibandingkan dengan bekatul tanpa fermentasi (Tabel 2). Sharma et al. (2016) melaporkan bahwa sereal sarapan dalam bentuk bubur yang disubstitusi dengan bekatul juga menunjukkan aktivitas antioksidan dan kadar total fenol yang lebih tinggi dibandingkan yang tidak ditambah bekatul. Namun dalam penelitian ini tidak dibandingkan antara bekatul dengan dan tanpa fermentasi.

Total serat pangan sereal sarapan yang disubstitusi dengan bekatul tanpa dan dengan fermentasi berkisar antara 6,31-7,53\% (bk). Total serat pangan tertinggi ditunjukkan oleh sereal sarapan yang disubstitusi dengan 25\% bekatul fermentasi (Tabel 3). Kamran et al. (2008) juga melaporkan hasil yang menyerupai, yaitu terjadinya peningkatan kadar serat pangan pada sereal sarapan yang disubstitusi dengan bekatul gandum. Sereal sarapan yang disubstitusi dengan bekatul fermentasi atau tanpa fermentasi memberikan kadar serat pangan lebih dari $6 \%$, sehingga dapat dikelompokkan sebagai sereal sarapan dengan kandungan serat pangan tinggi (BPOM, 2016).

\section{Mutu Fisik Sereal Sarapan}

Sereal sarapan yang diproses dengan teknologi ekstrusi panas mengakibatkan puffing yang dapat diukur dengan derajat pengembangan (Zhang et al., 2014). Penambahan bekatul mangakibatkan derajat pengembangan yang menurun pada persen substitusi yang semakin tinggi. Bekatul fermentasi pada persen substitusi yang sama secara nyata $(p<0,05)$ memberikan derajat pengembangan yang semakin rendah dibandingkan bekatul tanpa fermentasi (Figur 1). Derajat pengembangan tertinggi ditunjukkan oleh sereal sarapan yang disubstitusi dengan $15 \%$ bekatul tanpa fermentasi. Derajat pengembangan yang cenderung menurun dipengaruhi oleh adanya lemak, protein dan serat yang terkandung pada bekatul. Dari data komposisi kimia (Tabel 1), maka peningkatan substitusi bekatul ke dalam formula sereal sarapan memberikan kandungan protein, lemak dan serat pangan yang juga meningkat. Lemak dapat membentuk kompleks dengan pati dan protein yang menyebabkan air sulit untuk berpenetrasi ke dalam granula pati. Serat juga dapat menghalangi penetrasi air ke dalam granula pati (Harper, 1981; Santoso et al., 2007).

Tabel 1. Komposisi kimia tepung jagung, serta bekatul tanpa dan dengan fermentasi

\begin{tabular}{lccc}
\hline Komposisi & Tepung jagung & Bekatul tanpa fermentasi & $\begin{array}{c}\text { Bekatul dengan } \\
\text { fermentasi }\end{array}$ \\
\hline Air (\% bb) & $11,84 \pm 0,01^{\mathrm{c}}$ & $7,35 \pm 0,02^{\mathrm{a}}$ & $8,05 \pm 0,40^{\mathrm{b}}$ \\
Abu (\% bk) & $0,86 \pm 0,02^{\mathrm{a}}$ & $9,60 \pm 0,01^{\mathrm{b}}$ & $13,66 \pm 0,05^{\mathrm{c}}$ \\
Protein (\% bk) & $7,62 \pm 0,02^{\mathrm{a}}$ & $14,17 \pm 0,01^{\mathrm{b}}$ & $18,18 \pm 0,06^{\mathrm{c}}$ \\
Lemak (\% bk) & $2,63 \pm 0,02^{\mathrm{a}}$ & $18,23 \pm 0,01^{\mathrm{c}}$ & $14,24 \pm 0,07^{\mathrm{b}}$ \\
Karbohidrat (\%bk) & $77,05 \pm 0,03^{\mathrm{c}}$ & $50,65 \pm 0,03^{\mathrm{b}}$ & $45,87 \pm 0,58^{\mathrm{a}}$ \\
Serat pangan (\%bk) & $4,37 \pm 0,03^{\mathrm{a}}$ & $12,54 \pm 0,03^{\mathrm{b}}$ & $16,46 \pm 0,01^{\mathrm{c}}$ \\
\hline
\end{tabular}

Keterangan: Huruf yang berbeda dalam baris yang sama menunjukkan perbedaan yang nyata $(p<0,05)$. Data merupakan rata-rata dari tiga kali ulangan

Tabel 2. Aktivitas antioksidan dan total fenol dari bekatul tanpa dan dengan fermentasi

\begin{tabular}{lccc}
\hline Jenis bekatul & $\begin{array}{c}\text { AEAC } \\
(\mathrm{mg} / 100 \mathrm{~g})\end{array}$ & $\% \mathrm{RSA}$ & $\begin{array}{c}\text { Total fenol } \\
(\mathrm{mg} \text { EAG/100 g bk) }\end{array}$ \\
\hline Tanpa fermentasi & $145,16 \pm 48,16^{\mathrm{a}}$ & $66,28 \pm 1.04^{\mathrm{a}}$ & $1125,01 \pm 12,08^{\mathrm{a}}$ \\
Dengan fermentasi & $191,80 \pm 40,82^{\mathrm{b}}$ & $87,29 \pm 0.87^{\mathrm{b}}$ & $1400,06 \pm 8,74^{\mathrm{b}}$ \\
\hline Keterangan: Huruf yang berbeda dalam tiap kolom menunjukkan perbedaan yang nyata $(\mathrm{p}<0,05)$. Data merupakan rata-rata dari tiga kali \\
ulangan
\end{tabular}

Tabel 3. Aktivitas antioksidan, kadar total fenol dan kadar serat pangan sereal sarapan jagung yang disubstitusi dengan bekatul tanpa dan dengan fermentasi

\begin{tabular}{lccrrr}
\hline Jenis bekatul & $\begin{array}{c}\text { Persen } \\
\text { substitusi (\%) }\end{array}$ & $\begin{array}{c}\text { AEAC } \\
\text { (mg/100 g bk) }\end{array}$ & \%RSA & $\begin{array}{c}\text { Total fenol } \\
\text { (mg EAG/ } 100 \mathrm{~g} \\
\text { bk) }\end{array}$ & $\begin{array}{c}\text { Serat pangan } \\
(\% \mathrm{bk})\end{array}$ \\
\hline Tanpa fermentasi & 15 & $32,10 \pm 18,37^{\mathrm{a}}$ & $13,65 \pm 0,39^{\mathrm{a}}$ & $67,66 \pm 2,47^{\mathrm{a}}$ & $6,31 \pm 0,05 \mathrm{a}$ \\
& 20 & $50,85 \pm 1,89^{\mathrm{c}}$ & $22,5 \pm 0,04^{\mathrm{c}}$ & $130,59 \pm 0,88^{\mathrm{c}}$ & $6,72 \pm 0,02 \mathrm{~b}$ \\
Dengan & 25 & $98,75 \pm 22,32^{\mathrm{e}}$ & $45,46 \pm 0,50^{\mathrm{e}}$ & $144,64 \pm 5,75^{\mathrm{e}}$ & $6,91 \pm 0,05 \mathrm{c}$ \\
fermentasi & 15 & $38,68 \pm 0,44^{\mathrm{b}}$ & $16,72 \pm 0,01^{\mathrm{b}}$ & $104,83 \pm 1,78^{\mathrm{b}}$ & $6,86 \pm 0,04 \mathrm{c}$ \\
& 20 & $72,27 \pm 26,67^{\mathrm{d}}$ & $33,46 \pm 0,61^{\mathrm{d}}$ & $138,27 \pm 1,38^{\mathrm{d}}$ & $7,45 \pm 0,03 \mathrm{~d}$ \\
\hline
\end{tabular}

Keterangan: Huruf yang berbeda dalam tiap kolom menunjukkan perbedaan yang nyata $(p<0,05)$. Data merupakan rata-rata dari tiga kali ulangan 


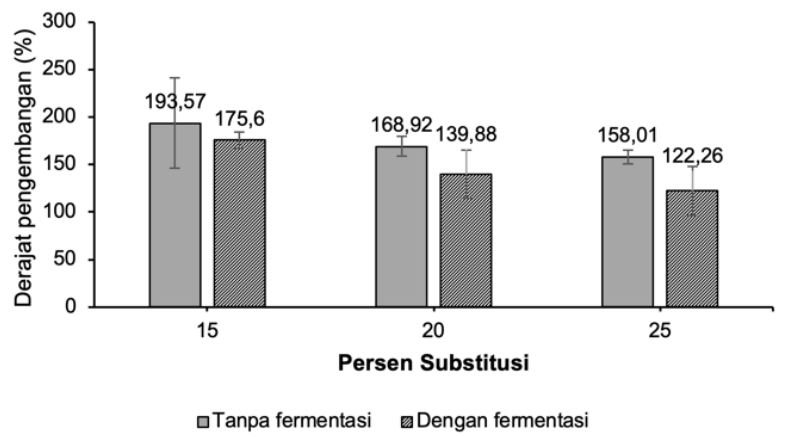

Figur 1. Derajat pengembangan sereal sarapan jagung yang disubstitusi dengan bekatul tanpa dan dengan fermentasi.

Data merupakan rata-rata dari tiga kali ulangan
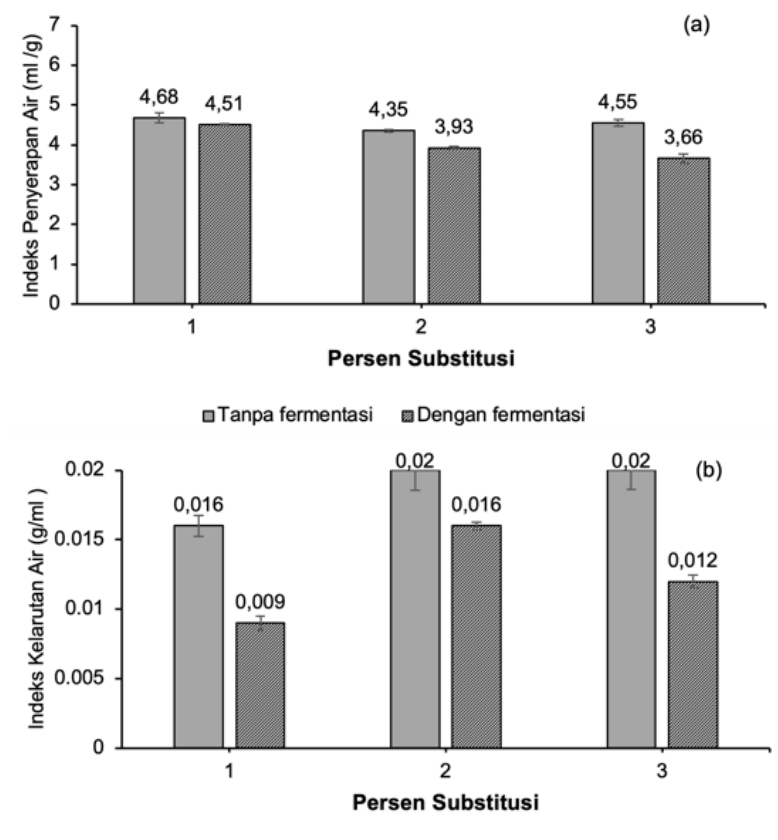

口Tanpa fermentasi aDengan fermentasi

Figur 2. Indeks penyerapan air (a) dan indeks kelarutan air (b) sereal sarapan jagung yang disubstitusi dengan bekatul tanpa dan dengan fermentasi

Penyerapan air dan kelarutan dalam air merupakan parameter penting dari sereal sarapan, karena sereal sarapan umumnya dikonsumsi dalam media cair (seperti susu). Indeks penyerapan air (IPA) dan indeks kelarutan air (IKA) dari sereal sarapan berhubungan dengan tingkat gelatinisasi dan kadar air produk. IPA yang menunjukkan kemampuan dari sereal sarapan dalam menyerap air dipengaruhi oleh adanya grup hidrofilik dan jumlah pati yang tergelatinisasi. Semakin tinggi pati yang tergelatinisasi dan semakin tinggi kadar air, maka IPA semakin tinggi (Santoso et al., 2007). Proses gelatinisasi juga mengakibatkan keluarnya amilosa dan amilopektin dari struktur granula yang menyebabkan peningkatan kelarutan. Peningkatan kelarutan ini dapat diukur dengan IKA yang menunjukkan kemampuan bahan dalam menyerap air. Sereal sarapan yang disubstitusi dengan bekatul secara umum memberikan IPA yang lebih tinggi dibandingkan sereal sarapan yang disubstitusi bekatul dengan fermentasi pada konsentrasi yang sama (Figur 2a). IPA sereal sarapan yang disubstitusi dengan bekatul fermentasi cenderung menurun pada persen substitusi yang semakin tinggi. Sereal sarapan yang disubstitusi dengan bekatul tanpa fermentasi juga memiliki IKA yang lebih tinggi dibandingkan sereal sarapan yang disubstitusi dengan bekatul fermentasi (Figur 2b). Sereal sarapan dengan substitusi bekatul tanpa fermentasi sebesar 20 atau $25 \%$ memiliki IKA tertinggi, sedangkan yang disubstitusi dengan bekatul tanpa fermentasi sebesar 25\% memiliki IKA terendah.
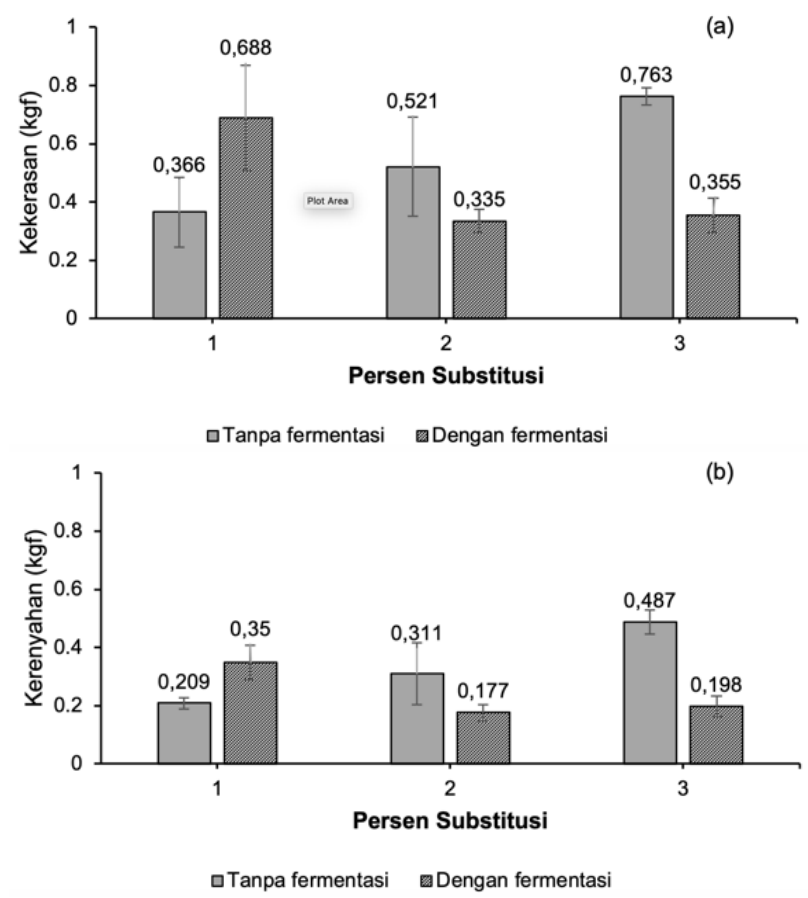

Figur 3. Kekerasan (a) dan kerenyahan (b) sereal sarapan jagung yang disubstitusi dengan bekatul tanpa dan dengan fermentasi

Sifat fisik penting lain dari sereal sarapan adalah kekerasan dan kerenyahan. Tekstur produk ekstrusi dipengaruhi oleh kandungan amilosa dan amilopektin bahan. Amilosa memiliki struktur yang linier sehingga lebih kompak ketika dikenai panas dan tekanan, sedangkan amilopektin memiliki struktur bercabang sehingga lebih bersifat mekar ketika dikenai panas dan tekanan (Zhang et al., 2014). Kekerasan sereal sarapan juga dipengaruhi oleh kandungan protein dan lemak pada bahan. Protein dan lemak dapat membentuk matriks seperti serat sehingga produk cenderung keras (Harper 1981).

Sereal sarapan yang disubstitusi dengan bekatul tanpa fermentasi, cenderung lebih keras dengan semakin tinggi persen substitusi bekatul (Figur 3a). Namun pada bekatul fermentasi, sereal sarapan cenderung menurun kekerasannya dengan semakin tinggi persen substitusi. Semakin tinggi substitusi bekatul tanpa fermentasi, sereal sarapan menjadi kurang renyah. Namun sereal sarapan yang substitusi dengan bekatul fermentasi menunjukkan semakin renyah dengan semakin tinggi persen substitusi bekatul (Figur 3b). Kekerasan dan kerenyahan dapat disebabkan oleh perbedaan rasio amilosa dan amilopektin. Amilosa berperan dalam menghasilkan tekstur yang keras, sedangkan amilopektin berperan untuk memberikan tekstur yang renyah. Amilosa 
memiliki struktur rantai lurus sehingga menjadi lebih kompak ketika dikenai tekanan dan suhu yang tinggi selama proses ekstrusi (Zhang et al., 2014). Olanipekun et al. (2009) menyatakan bahwa amilosa pada tepung kedelai menurun setelah fermentasi oleh Rhizopus oligosporus selama 72 jam yang diduga digunakan untuk pertumbuhan kapang. Penurunan kandungan amilosa pada substitusi bekatul fermentasi diduga yang menyebabkan penurunan kekerasan dan peningkatan kerenyahan.

\section{Mutu sensori sereal sarapan}

Hasil uji kesukaan oleh panelis terhadap sereal sarapan yang disubstitusi dengan bekatul fermentasi dan tanpa fermentasi disajikan pada Tabel 4. Secara umum, penerimaan sensori sereal sarapan yang disubstitusi dengan bekatul tanpa fermentasi lebih baik dibandingkan yang disubstitusi dengan bekatul fermentasi untuk parameter warna, rasa, aroma, kekerasan dan penerimaan keseluruhan pada rentang penerimaan netral hingga agak suka. Berdasarkan penerimaan keseluruhan, sereal sarapan yang disubstitusi dengan $25 \%$ bekatul tanpa fermentasi paling disukai. Sereal sarapan yang disubstitusi dengan bekatul fermentasi memberikan after taste agak pahit sehingga kurang diterima, walaupun memberikan penerimaan tekstur (kekerasan dan keranyahan) yang lebih disukai. Peningkatan senyawa fenolik pada bekatul fermentasi diduga berkontribusi pada pembentukan rasa pahit tersebut.

\section{Formulasi sereal sarapan terpilih}

Sereal sarapan dengan substitusi bekatul dipilih berdasarkan karakteristik fungsional (aktivitas antioksidan, total fenol, kadar serat pangan), mutu fisik (derajat pengembangan, IPA, IKA, kekerasan, kerenyahan) dan sensori (warna, aroma, rasa, kekerasan dan penerimaan keseluruhan). Pemilihan formula dilakukan dengan cara memberikan nilai/skor 1 sampai 6 dari setiap parameter (parameter yang diinginkan meningkat diberikan skor yang lebih tinggi), lalu masing-masing skor untuk parameter yang sama dijumlahkan (Tabel 5). Parameter yang memiliki skor yang sama menunjukkan hasil analisis yang tidak berbeda nyata. Berdasarkan urutan total skor, maka sereal sarapan yang disubstitusi dengan $25 \%$ bekatul tanpa fermentasi memberikan total skor yang paling tinggi (52).

Sereal sarapan yang disubstitusi dengan $25 \%$ bekatul tanpa dan dengan fermentasi menunjukkan aktivitas antioksidan, total fenol dan serat kasar yang relatif tinggi (Tabel 3). Sereal sarapan yang disubstitusi dengan $25 \%$ bekatul tanpa fermentasi juga memiliki relatif mengembang, menyerap dan larut dalam air (Figur 1 dan 2). Sereal sarapan yang disubstitusi dengan bekatul fermentasi $20-25 \%$ mengandung komponen bioaktif yang relatif tinggi dibandingkan yang disubstitusi

Tabel 4. Kesukaan panelis terhadap sereal sarapan yang disubstitusi bekatul

\begin{tabular}{|c|c|c|c|c|c|c|}
\hline \multirow{2}{*}{ Atribut } & \multicolumn{3}{|c|}{ Bekatul Tanpa fermentasi } & \multicolumn{3}{|c|}{ Bekatul dengan Fermentasi } \\
\hline & $15 \%$ & $20 \%$ & $25 \%$ & $15 \%$ & $20 \%$ & $25 \%$ \\
\hline Warna & $4,7 \pm 0,15^{\mathrm{cd}}$ & $5,1 \pm 0,10^{d}$ & $4,5^{c}$ & $3,8 \pm 0,10^{a b}$ & $3,9 \pm 0,05^{b}$ & $4,5+0,10^{c}$ \\
\hline Aroma & $4,3 \pm 0,11 \mathrm{abc}$ & $4,5 \pm 0,07^{c}$ & $4,5 \pm 010^{b c}$ & $4,1 \pm 0,10^{\mathrm{ab}}$ & $4,0 \pm 0,12^{\mathrm{a}}$ & $4,1+0,08^{a b c}$ \\
\hline Rasa & $4, \overline{7} \pm 0,05^{c}$ & $4,7+0,10^{c}$ & $4,8 \pm 0,11^{c}$ & $4,2 \pm 0,15^{b}$ & $3,8 \pm 0,10^{a b}$ & $3,6 \pm 0,20^{a}$ \\
\hline Kekerasan & $5,0 \pm 0,20^{b}$ & $4,4 \pm 0,15^{a}$ & $5,1 \pm 0,16$ & $4,4 \pm 0,20^{a}$ & $4,7 \pm 0,12^{\mathrm{ab}}$ & $4,8 \pm 0,11^{a b}$ \\
\hline Keseluruhan & $4,9 \pm 0,07^{d}$ & $4,8 \pm 0,10^{\text {cd }}$ & $5,0 \pm 0,13^{d}$ & $4,5 \pm 0,11^{b c}$ & $4,2 \pm 0,08^{a b}$ & $4,0 \pm 15^{a}$ \\
\hline
\end{tabular}

Keterangan: Huruf yang berbeda dalam tiap baris menunjukkan berbeda nyata $(p<0,05)$.

Tabel 5. Skor masing-masing parameter sereal sarapan sebagai pertimbangan dalam memilih formulasi terbaik

\begin{tabular}{|c|c|c|c|c|c|c|}
\hline \multirow[t]{2}{*}{ Parameter } & \multicolumn{3}{|c|}{ Bekatul Tanpa Fermentasi } & \multicolumn{3}{|c|}{ Bekatul dengan Fermentasi } \\
\hline & $15 \%$ & $20 \%$ & $25 \%$ & $15 \%$ & $20 \%$ & $25 \%$ \\
\hline \multicolumn{7}{|l|}{ Parameter kimia } \\
\hline AEAC & 1 & 3 & 5 & 2 & 4 & 5 \\
\hline RSA & 1 & 3 & 5 & 2 & 4 & 6 \\
\hline Total fenol & 1 & 3 & 5 & 2 & 4 & 6 \\
\hline Serat pangan & 1 & 2 & 3 & 3 & 4 & 5 \\
\hline \multicolumn{7}{|l|}{ Parameter fisik } \\
\hline Derajat pengembangan & 6 & 4 & 3 & 5 & 2 & 1 \\
\hline IPA & 5 & 3 & 4 & 4 & 2 & 1 \\
\hline IKA & 3 & 4 & 4 & 1 & 3 & 2 \\
\hline Kekerasan & 4 & 3 & 1 & 2 & 5 & 4 \\
\hline Kerenyahan & 4 & 3 & 1 & 2 & 6 & 5 \\
\hline \multicolumn{7}{|l|}{ Parameter sensori } \\
\hline Warna & 3 & 4 & 2 & 1 & 1 & 2 \\
\hline Aroma & 3 & 4 & 4 & 2 & 1 & 2 \\
\hline Rasa & 4 & 4 & 4 & 3 & 2 & 1 \\
\hline Kekerasan & 4 & 5 & 6 & 1 & 3 & 3 \\
\hline Penerimaan keseluruhan & 4 & 5 & 5 & 3 & 2 & 1 \\
\hline Total skor & 44 & 50 & 52 & 33 & 43 & 44 \\
\hline
\end{tabular}


bekatul tanpa fermentasi, namun dari penerimaan organoleptik lebih rendah. Berdasarkan pertimbangan tersebut, maka formulasi sereal sarapan yang dipilih adalah yang disubstitusi dengan $25 \%$ bekatul tanpa fermentasi. Persentase bekatul terpilih ini lebih tinggi dibandingkan yang dilaporkan oleh Budijanto et al. (2012), yaitu $20 \%$. Hasil analisis proksimat menunjukkan sereal sarapan ini mengandung air (5,94\%bb), abu $(2,90 \% \mathrm{bb})$, protein $(9,32 \% \mathrm{bb})$, lemak $(2,68 \% \mathrm{bb})$, dan karbohidrat $(79,16 \% \mathrm{bb})$, yang memenuhi kandungan yang dipersyaratkan dalam SNI 01-2886-2000 (BSN, 2000).

\section{Kesimpulan}

Proses fermentasi bekatul dengan kapang Rhizopus oligosporus selama 72 jam dapat meningkatkan kadar abu, protein, lemak, serat kasar, aktivitas antioksidan, dan total fenol. Sereal sarapan yang disubstitusi dengan $25 \%$ bekatul tanpa fermentasi adalah yang paling disukai dari segi warna, rasa, dan aroma. Sereal sarapan tersebut menunjukkan kemampuan aktivitas antioksidan, kadar total fenol dan serat pangan yang cukup tinggi, serta memiliki derajat pengembangan, kekerasan dan kerenyahan yang dapat diterima.

\section{Daftar Pustaka}

Andarwulan, N., Shetty, K. 1999. Phenolic content in differentiated tissue and culture of transformed and agrobacterium-transformed roots of anise (Pimpinella anisum L). Journal Agricultural and Food Chemistry 47:1776-1780. DOI: 10.1021/jf981214r.

AOAC (Association of Official Analytical Chemist). 2005. Official Methods of Analysis of AOAC International, $18^{\text {th }}$ ed.

BPOM-RI (Badan Pengawas Obat dan Makanan Republik Indonesia). 2016. Peraturan Kepala Badan Pengawas Obat dan Makanan Republik Indonesia tentang Pengawasan Klaim pada Label dan Iklan Pangan Olahan, Jakarta.

BPS (Badan Pusat Statistik). 2018. Luas Panen dan Produksi Padi di Indonesia. http://www.bps.go.id. (Diakses tanggal 02 Januari 2019).

Brunschwiler, C., Heine, D., Kappeler,S. Conde-Petit, B., Nyström, L. 2013. Direct measurement of rice bran lipase activity for inactivation kinetics and storage stability prediction. Journal of Cereal Science 58(2):272-277. DOI:10.1016/j.jcs.2013.06.007.

BSN (Badan Standardisasi Nasional). 2000. SNI 012886-2000. Makanan Ringan Ekstrudat. Badan Standardisasi Nasional, Jakarta.

BSN (Badan Standardidasi Nasional). 2006. SNI 012346-2006. Cara Uji Makanan Minuman. Badan Standardisasi Nasional, Jakarta.

Budijanto, S., Sitanggang, A.B., Wiaranti, H., Koesbiantoro, B. 2012. Pengembangan teknologi sereal sarapan bekatul dengan menggunakan twin screw extruder. Jurnal Pascapanen 9(2):63-69. DOI:10.21082/jpasca.v9n2.2012.63-69.
Cempaka, L., ,Eliza, N., „Ardiansyah , Handoko, D.D., Astuti, R.M. 2018. Proximate composition, total phenolic content, and sensory analysis of rice bran tempeh. Makara Journal of Science 22(2):89-94. DOI:10.7454/mss.v22i2.9616.

Chipurura, B., Muchuweti,M., Manditseraa, F. 2010. Effects of thermal treatment on the phenolic content and antioxidant activity of some vegetables. Asian Journal of Clinical Nutrition 2(3):93-100. DOI:10.3923/ajcn.2010.93.100.

Dlamini, N.S., Solomon, W.K. 2016. Effect of ingredients ratio on physicochemical and sensory properties of sorghum, maize and soya protein concentrate blend extrudates. International Journal of Food Science and Nutrition Engineering 6(5):112-120. DOI:10.5923/j.food.20160605.02.

Faizah, Kusnandar, F., Nurjanah, S. 2020. Senyawa fenolik, oryzanol, dan aktivitas antioksidan bekatul yang difermentasi dengan Rhizopus oryzae. Jurnal Teknologi dan Industri Pangan 31(1):86-94. DOI:10.6066/jtip.2020.31.1.86.

Ghatak, S.B., Panchal, S.J. 2012. Anti-hyperlipidemic activityo of oryzanol, isolated from crude rice bran oil, on triton WR-1339-induced acute hyperlipidemia in rats. Revista Brasileira de Farmacognosia 22(3):642-648. DOI:10.1590/ S0102-695X2012005000023.

Gul, K., Yousuf, B., Singh, A.K., Singh, P., Wani, A.A. 2015. Rice bran: nutritional values and its emerging potential for development of functional food: a review. Bioactive Carbohydrates and Dietary Fibre 6(1):24-30. DOI:10.1016/ j.bcdf.2015.06.002.

Harper, J.M. 1981. Extrusion of Food. Vol II. Boca Roton: CRS Press.

Henderson, A.J., Ollila, C.A., Kumar, A., Borresen, E.C., Raina, K., Agarwal, R., Ryan, E.P. 2012. Chemopreventive properties of dietary rice bran: current status and futur prospects. Advances in Nutrition 3(5):643-653. DOI:10.3945/an. 112.002303.

Jun, H.I., Shin, J.W., Yang, G.S., Kim, Y.S. 2015. Isolation and identification of phenolic antioxidants in black rice bran. Journal of Food Science 80: 262-268. DOI:10.1111/1750-3841.12754.

Kamran, M., Saleem, N., Umer, Z.N. 2008. Ready-to-eat (RRTE) wheat bran breakfast cereal as a highfiber diet. Journal of Food Processing and Preservation 32(5):863-867. DOI:10.1111/j.17454549.2008.00218.x.

Luh, S. 1991. Rice Production and Utilization. The Avi Publication, Westport, USA.

Martins, S., Mussatto, S.I., Martinez, A.G., Montanez, S.J., Aguilar, C.N., Teixeira, J.A. 2011. Bioactive phenolic compounds: Production and extraction by solid-state fermentation: a review. Biotechnology Advances 29(3):365-373. DOI:10.1016/j. biotechadv.2011.01.008.

Moongngarm, A., Daomukda, N., Khumpika, S. 2012. Chemical compositions, phytochemicals, and antioxidant capacity of rice bran, rice bran layer, 
and rice germ. Asia-Pacific Chemical Biology Environmental Engineering Procedia 2:73-79. DOI:10.1016/ j.apcbee.2012.06.014.

Muntana, N., Prasong, S. 2010. Study on total phenolic contents and their antioxidant activities of thai white, red and black rice bran extracts. Pakistan Journal of Biological Sciences 13(4):170-174.

Novelli, P.K., Barros, M.M., Fleuri, L.F. 2016. Novel inexpensive fungi proteases : production by solid state fermentation and characterization. Journal of Food Chemistry 198:119-124. DOI:10.1016/j.foodchem.2015.11.089.

Olanipekun, B.F., Otunola, E.T., Odelakun, O.E., Oyelade, O.J. 2009. Effect of fermentation with Rhizopus oligosporus on some physicochemical properties of starch extracts from soybean flour. Food and Chemical Toxicology 47(7): 1401-1405. DOI:10.1016/j.fct.2009.02.023.

Oliveira, M.S., Fedden, V., Kupski, L., Cipolatti, E.P., Furlong, E.B., Soares, L,S. 2010. Physicochemical characterization of fermented rice bran biomass. CyTA-Journak of Food 8:229-236. DOI: $10.1080 / 19476330903450274$.

Oliveira, L.C., Alencar, N.M.M., Steel, C.J. 2018. Improvement of sensorial and technological characteristics of extruded breakfast cereals enriched with whole grain wheat flour and jabuticaba (Myrciaria cauliflora) peel. LWT Food Science and Technology 90:207-214. DOI: 10.1016/j.Iwt.2017.12.017.

Purwanto, A., Astri, N.F., Dewi, W. 2014. Pengaruh jenis pelarut terhadap rendemen dan aktivitas antioksidan dalam eksrak minyak bekatul padi (rice bran oil). Ekuilibrium 13(1):29-34.

Pengkumsri, N., Chaiyasut, C., Saenjum, C., Sirilun, S., Peerajan, S., Suwannalert, P., Sirisattha, S., Sivamaruthi, B.S. 2015. Physicochemical and antioxidative properties of black, brown and red rice varieties of Northern Thailand. Food Science and 35(2):331-338. DOI:10.1590/1678-457X.6573.

Rao, B.S.N. 2000. Nutritive Value of Rice Bran. Nutrition Foundation of India.

Rashid, N.Y.A., Razak, D.L.A., Jamaluddin, A., Sharifuddin, S.A., Long, K. 2015. Bioactive compounds and antioxidant activity of rice bran fermented with lactic acid bacteria. Malaysian Journal of Microbiology 11(2):156-162. DOI:10.21161/mjm.12714.

Razak, D.L.A., Rashid, N.Y.A.R., Jamaluddin, A., Sharifudin, S.A., Long, K. 2015. Enhancement of phenolic acid content and antioxidant activity of rice bran fermented with Rhizopus oligosporus and Monascus purpureus. Biocatalysis and Agricultural Biotechnology 4(1):33-38. DOI:10.1016/j.bcab.2014.11.003.

Ryan, E.P., Heuberger, A.L., Weir, T.L., Barnett, B., Broeckling, C.D., Prenni, J.E. 2011. Rice bran fermented with Saccharomyces boulardii generates novel metabolite profile with bioactivity.
Journal Agriculture and Food Chemistry 59(5):1862-1870. DOI:10.1021/jf1038103.

Santoso, U., Triastati, M., Mudjisihono, R. 2007. Produk ekstrusi berbasis ubi jalar. Jurnal Teknologi dan Industri Pangan 18(1):40-46.

Schmidt, C.G., Furlong, E.B. 2012. Effect of particle size and ammonium sulfate concentration on rice bran fermentation with the fungus Rhizopus oryzae. Bioresource Technology 123:36-41. DOI:10.1016/j.biotech.2012.07.081.

Schmidt, C.G., Goncalves, L.M., Prietto, L., Hackbart, H.S., Furlong, E.B. 2014. Antioxidant activity and enzyme inhibition of phenolic acids from fermented rice bran with fungus Rizhopus oryzae. Food Chemistry 124:132-140. DOI: 10.1016/j.foodchem.2013.09.101.

Sharif, M.K., Butt, M.S., Anjum, F.M., Khan, S.H. 2014. Rice Bran: A Novel Functional Ingredient. Critical Reviews in Food Science and Nutrition 54(6):807816. DOI:10.1080/10408398.2011.608586.

Sharma, S, Dar, B.N., Nayik, G.A., Kaurm G. 2016. Total phenolic content and antioxidant activity of cereal bran enriched ready to eat breakfast cereal porridge. Current Nutrition and Food Science 12(2):142-149. DOI:10.2174/1573401312666160 323000523

Silveira, C.M., Furlong, E.B. 2009. The effects of solidstate fermentation in the functional properties of defatted rice bran and wheat bran. Brazilian Archives of Biology and Technology 52(6). DOI: 10.1590/S1516-89132009000600027.

Sivamaruthi, B.S., Kesika, P., Chaiyasut, C. 2018. A comprehensive review on functional properties of fermented rice bran. Pharmacognosy Reviews 12(24): 218-224. DOI:10.4103/phrev.phrev 11_18.

Sompong, R., Siebenhandl-Ehn, S., Linsberger-Martin, G., Berghofer, E.. 2011. Physicochemical and antioxidative properties of red and black rice varieties from Thailand, China and Sri Lanka. Food Chemistry 124:132-140. DOI:10.1016/j.foodchem. 2010.05.115.

Sousa, B.A., Correia, R.T.P. 2012. Phenolic content, antioxidant activity and antiamylolytic activity of extracts obtained from bioprocessed pineapple and guava wastes. Journal of Chemical Engineering 29(1):25-30. DOI:10.1590/S010466322012000100003.

Thomas, R.G., Perhssona, P.R., Ahujaa, JKC, Smiejab, E., Millerc, K.B. 2013. Recent trends in ready-toeat breakfast cereals in the U.S. Procedia Food Science 2:20-26. DOI:10.1016/. profoo.2013. 04.005.

Tuarita, M.Z., Sadek, N.F., Sukarno, Yuliana, N.D., Budijanto, S. 2017. Pengembangan bekatul sebagai pangan fungsional: Peluang, hambatan, dan tantangan. Jurnal Pangan 26(2):167-176. DOI:10.33964/jp.v26i2.354.

Vong, W.C., Hua, X.Y., Liu, S.Q. 2018. Solid-state fermentation with Rhizopus oligosporus and Yarrowia lipolytica improved nutritional and flavour 
properties of okara. LWT Journal 90:316-322. DOI:10.1016/j.Iwt.2017.12.050.

Xu, Z., Hua, N., Godber, J.S. 2001. Antioxidant activity of tocopherols, tocotrienols, and gamma-oryzanol components from rice bran against cholesterol oxidation accelerated by 2,2'-azobis(2methylpropionamidine) dihydrochloride. Journal of
Agriculture and Food Chemistry 49(4):2077-81. DOI:10.1021/jf0012852.

Zhang, C., Zhang, H., Wang, L., Qian, H. 2014. Physical, functional, and sensory characteristics of cereal extrudates. International Journal of Food Properties 17(9):1921-1933. DOI:10.1080/ 10942912.2013.767831. 